\title{
Determinan Perencanaan Pajak Perusahaan Pertambangan di Indonesia
}

\author{
Agustina $^{1 *}$, Mie Mie $^{2}$, Syafira $^{3}$ \\ Universitas Mikroskil ${ }^{1,2,3}$ \\ agustina@mikroskil.ac.id, miemie.tay@mikroskil.ac.id, syafira.firza@mikroskil.ac.id
}

*Corresponding Author

Diajukan : 26 Nopember 2021

Disetujui : : 1 Desember 2021

Dipublikasi : 1 Januari 2022

\begin{abstract}
This research aims to determine the effect of corporate governance, solvability, profitability, company size, growth opportunity, and capital intensity ratio on tax planning. The population in this research were all mining companies listed on Indonesia stock exchange for the 2015-2018. This type of research was causal associative, with data analysis method, namely confirmatory factor analysis and then continued with multiple regression analysis. The result of the factor test indicate that the audit committee is not a determinant of tax planning. Based on the results of regression analysis shows that simultaneously, institutional ownership, the proportion of independent commissioners, board of directors, solvency, profitability, company size, growth opportunity, and capital intensity ratio have an effect on tax planning. Partially, the results of the study indicate that institutional ownership, profitability, growth opportunity, and capital intensity ratio can be determinants that affect corporate tax planning. Meanwhile, the proportion of independent commissioners, board of directors, solvency, and company size partially not influence the company to do the tax planning. From results of this research, the government is expected will pay more attention to the grey area that can be used by companies as a gap to reduce tax payments which results in reduced state revenues.
\end{abstract}

Keywords: capital intensity ratio; corporate governance; growth opportunity; profitability; tax planning

\section{PENDAHULUAN}

Pajak merupakan iuran yang dibayarkan kepada pemerintah yang sifatnya wajib dan memaksa dari orang pribadi maupun badan tanpa adanya imbalan langsung yang akan diberikan dan digunakan untuk keperluan negara dalam memakmurkan rakyat. Meskipun bertujuan untuk mencapai kesejahteraan umum, wajib pajak tidak selalu menerima dengan baik kewajiban pembayaran pajak ini, khususnya wajib pajak badan. Dikarenakan hal ini, maka pada tahun 2008, pemerintah Indonesia merevisi Undang-Undang Perpajakan di mana wajib pajak diberikan insentif berupa pengurangan tarif pajak yang dibayarkan. Walaupun demikian, pajak merupakan beban yang dapat mempengaruhi jumlah laba bersih yang diterima sehingga perusahaan akan berusaha membayar pajak sekecil-kecilnya sekalipun adanya regulasi pengurangan tarif. Salah satu upaya perusahaan dalam mengurangi beban pajak adalah dengan melakukan tax planning. 
Owner: Riset \& Jurnal Akuntansi

e-ISSN : 2548-9224 | p-ISSN : 2548-7507

Volume 6 Nomor 1, Januari 2022

DOI : https://doi.org/10.33395/owner.v6i1.567

\begin{tabular}{|c|c|c|c|}
\hline \multirow{3}{*}{$\begin{array}{l}\text { Summary of the tax structure in } \\
\text { Indonesia }\end{array}$} & \multicolumn{3}{|c|}{ Tax Revenues in nationai currency } \\
\hline & \multicolumn{3}{|c|}{ Indonesian Rupiah. Billions } \\
\hline & 2017 & 2016 & $\Delta$ \\
\hline Taxes on income, profits and capital gains & 646793473 & 666212380 & -19410918 \\
\hline of which & - & - & + \\
\hline Personal income, profits and gains & 294888438 & 380045141 & -85156703 \\
\hline Corporate income and gains & 351905035 & 286167247 & +65737788 \\
\hline Social security contributions & 54401398 & 47220435 & +7180963 \\
\hline Taxes on goods and services & 673226331 & 591209149 & +82017182 \\
\hline of which & $=$ & - & 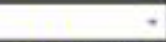 \\
\hline Value added taxes / Goods and services tax & 480724607 & 412213454 & $+68511,153$ \\
\hline Taxes on specific goods and services & 192501724 & 178995696 & +13506028 \\
\hline of which & - & - & - \\
\hline Excises & 153288149 & 143525035 & +9763114 \\
\hline Customs and import duties & 35066181 & 32472077 & +2594104 \\
\hline Other taxes & 192307900 & 184715707 & +7692261 \\
\hline TOTAL & $1566729 \quad 170$ & 1489357679 & $+77.37+491$ \\
\hline
\end{tabular}

Gambar 1 Ringkasan Struktur Pajak di Indonesia

Sumber : OECD

Berdasarkan perhitungan statistik pendapatan yang dilakukan oleh Organization for Economic Co-operation and Development (OECD) (Gambar 1) menunjukkan bahwa penerimaan pajak badan di Indonesia tahun 2016-2017 sangat mempengaruhi total penerimaan pajak di Indonesia. Perencanaan pajak merupakan salah satu upaya yang dilakukan perusahaan dalam rangka menekan pembayaran pajak. Di sisi lain, pemerintah dirugikan dengan tindakan perencanaan pajak yang dilakukan perusahaan, karena produk domestic bruto dari masyarakat ingin diserap kembali oleh pemerintah dalam bentuk pajak. Industri batubara selama beberapa dekade selalu menjadi sektor favorit oleh negara karena kontribusinya yang cukup besar bagi perekonomian Indonesia.

Pada saat krisis ekonomi global 2008, industri batu bara turut andil dalam perbaikan kondisi ekonomi Indonesia. Hal ini menyebabkan kurangnya pengawasan terhadap industri pertambangan batubara, yang berujung pada kasus praktik seperti penggelapan pajak. Berdasarkan informasi yang terdapat dalam (Katadata, 2020), Badan Pusat Statistik menunjukkan data bahwa dari mulai tahun 2014 sampai 2018, industri pertambangan batubara rata-rata memberikan kontribusi 2,3\% dari produk domestik bruto per tahun atau senilai Rp. 235 triliun. Namun dibalik besarnya nilai ekonomi yang disumbangkan oleh industri pertambangan batubara, ternyata kontribusi pajak yang dibayarkan oleh industri ini sangat kecil. Kementerian Keuangan menjelaskan rasio pajak untuk sektor pertambangan mineral dan batubara pada tahun 2016 hanya 3,9\%, sedangkan rasio pajak nasional 10,8\%. Dari fenomena rasio pajak industri pertambangan batu bara tersebut, mengindikasi bahwa perusahaan yang berada di sektor tersebut melakukan perencanaan pajak. Hal ini dikarenakan, rasio pajak tidak terlepas dari issue perencanaan pajak yang dilakukan oleh perusahaan. Serangkaian kebijakan dapat diambil oleh perusahaan guna menurunkan beban pajak yang harus dibayar termasuk dalam pemilihan metode akuntansi. Perencanaan pajak yang efektif dapat diukur dengan tarif pajak efektif (effective tax rate). Nilai tarif pajak efektif merupakan cerminan dari seberapa mampu sebuah perusahaan mengelola pajaknya dengan baik.

Upaya perusahaan untuk mengurangi nilai pembayaran pajak dalam tax planning dapat dilakukan secara legal dengan cara memanfaatkan grey area perpajakan. Meskipun tax planning dilakukan secara legal, pemerintah tidak membenarkan hal tersebut karena tindakan perencanaan pajak membuat pemerintah sulit untuk menyerap kembali produk domestik bruto dari masyarakat dalam bentuk pajak. Adapun determinan yang akan diuji dalam penelitian ini adalah tata kelola perusahaan (diukur dengan Kepemilikan institusional, proporsi dewan komisaris independen, komite audit, dewan direksi), solvabilitas, profitabilitas, ukuran perusahaan, peluang pertumbuhan dan 
Owner: Riset \& Jurnal Akuntansi

e-ISSN : 2548-9224 | p-ISSN : 2548-7507

Volume 6 Nomor 1, Januari 2022

DOI : https://doi.org/10.33395/owner.v6i1.567

capital intensity ratio.

, Berdasarkan penelitian-penelitian terdahulu terdapat faktor-faktor yang dapat mempengaruhi tindakan perusahaan dalam melakukan perencanaan pajak. Penelitian yang dilakukan oleh (Putra, Yuliusman, \& Wisra, 2020) menunjukkan bahwa Kepemilikan Institusional dan Profitabilitas berpengaruh terhadap perencanaan pajak. Hasil penelitian oleh (Hazir, 2019) menyatakan bahwa Ukuran Perusahaan dan Solvabilitas berpengaruh terhadap perencanaan pajak. Kemudian, hasil penelitian yang dilakukan oleh (Fauzan, Wardan, \& Nurharjanti, 2019) menujukkan bahwa Peluang Pertumbuhan dan Komite Audit berpengaruh terhadap Perencanaan Pajak. Selain itu, penelitian yang dilakukan oleh (Mappadang, 2021) menunjukkan bahwa Proporsi Dewan Komisaris Independen berpengaruh terhadap Perencanaan Pajak. Penelitian yang dilakukan oleh (Idzniah \& Bernawati, 2020) menyatakan bahwa Dewan Direksi berpengaruh terhadap Perencanaan Pajak. Faktor terakhir berdasarkan hasil penelitian yang dilakukan oleh (Ayem \& Setyadi, 2019) menunjukkan bahwa Capital Intensity Ratio berpengaruh terhadap perencanaan pajak perusahaan. Namun penelitian yang dilakukan oleh (Gunawan, Christy, Tin, \& Jonathan, 2021) menunjukkan bahwa Komite Audit tidak berpengaruh terhadap Perencanaan Pajak. Hasil penelitian yang dilakukan oleh (Indriani \& Juniarti, 2020) menunjukkan bahwa Ukuran Perusahaan, Peluang Pertumbuhan, dan Profitabilitas tidak berpengaruh terhadap Perencanaan Pajak. Penelitian yang dilakukan oleh (Chytis, Taslos, \& Filos, 2020) menunjukkan bahwa Solvabilitas, Kepemilikan Institusional, dan Dewan Direksi tidak berpengaruh terhadap Perencanaan Pajak. Kemudian, hasil penelitian yang dilakukan oleh (Pattiasina, Tammubua, Numberi, Patiran, \& Temalagi, 2019) menunjukkan bahwa Capital Intensity Ratio dan Proporsi Dewan Komisaris Independen tidak berpengaruh terhadap Perencanaan Pajak.

\section{Perencanaan Pajak}

\section{STUDI LITERATUR}

Upaya yang dapat dilakukan oleh perusahaan diantaranya adalah dengan meminimalkan beban pajak dalam batas yang tidak melanggar aturan, karena pajak merupakan salah satu faktor pengurang laba. Semakin besar penghasilan, semakin besar pula pajak yang terutang. Oleh karena itu perusahaan membutuhkan perencanaan pajak atau tax planning yang tepat agar perusahaan membayar pajak dengan efisien. Tax planning adalah suatu proses mengorganisasi usaha wajib pajak sedemikian rupa agar utang pajaknya baik pajak penghasilan maupun pajak lainnya berada dalam jumlah minimal, selama hal tersebut tidak melanggar ketentuan undang-undang. Tidak ada yang salah dengan melakukan perencanaan untuk menghindari pajak asalkan menggunakan metode yang legal. Perencanaan perpajakan dimulai pada saat akan mendirikan perusahaan (pemilihan bentuk usaha, pemilihan metode pembukuan, pemilihan lokasi usaha); saat menjalankan usaha (pemilihan transaksi-transaksi yang akan dilakukan dalam kegiatan operasionalnya, pemilihan metode akuntansi dan perpajakan, tanggung jawab terhadap stakeholders); saat akan menutup usaha (restrukturisasi usaha/perusahaan, likuidasi, merger, pemekaran, dan sebagainya) (Pohan, 2013).

Perusahaan publik dituntut harus menerapkan tata kelola perusahaan yang baik untuk meminimalisasi konflik keagenan. Agency relationship terjadi saat pemilik perusahaan mengontrak agen yaitu manajer untuk melakukan jasanya dan memberikan kekuasaan kepada agen dalam pembuatan keputusan yang terbaik untuk pemilik perusahaan. Adanya kekuasaan tersebut sering mengakibatkan konflik yang didasari oleh kepentingan masing-masing pihak dimana pemilik saham berfokus pada peningkatan nilai saham, sedangkan manajer berfokus pada pemenuhan kepentingan pribadinya yang berhubungan dengan perusahaan. Disinilah peran sistem tata kelola perusahaan yang baik dianut dan dipatuhi oleh manajer perusahaan agar bertindak tidak hanya berdasarkan kepentingannya. Oleh karena itu, penerapan tata kelola perusahaan yang baik diharapkan dapat mempengaruhi perusahaan untuk menentukan kebijakan perpajakan yang akan digunakan. 
Owner: Riset \& Jurnal Akuntansi

e-ISSN : 2548-9224 | p-ISSN : 2548-7507

Volume 6 Nomor 1, Januari 2022

DOI : https://doi.org/10.33395/owner.v6i1.567

\section{Kepemilikan Institusional terhadap Perencanaan Pajak}

Kepemilikan institusional akan mampu mengurangi masalah keagenan yang terjadi karena pemegang saham institusional akan mengawasi perusahaan sehingga mengurangi tindakan manajer perusahaan yang mementingkan diri sendiri (Hery, 2017). Perusahaan dengan kepemilikan institusional yang mayoritas menunjukkan kemampuannya untuk memonitor manajemen perusahaan. Kepemilikan institusional yang mendominasi di suatu perusahaan akan meningkatkan pengawasan yang lebih optimal terhadap kinerja dan kebijakan yang dibuat oleh manajemen. Perencanaan perpajakan merupakan bagian yang tidak terpisahkan dari kebijakan manajemen perusahaan. Perencanaan perpajakan dilakukan dengan cara memilih metode akuntansi dan perpajakan yang tepat sehingga dapat dipertanggungjawabkan terhadap stakeholders (Pohan, 2013).

Biasanya di dalam suatu perusahaan, proporsi kepemilikan institusional memiliki porsi yang signifikan terhadap saham beredar perusahaan. Hal ini mengakibatkan secara tidak langsung investor institusional memiliki kendali yang besar dalam kegiatan operasional perusahaan. Pernyataan ini didukung oleh hasil penelitian yang dilakukan oleh (Khan, Srinivasan, \& Tan, 2017), (Putra, Yuliusman, \& Wisra, 2020), (Sonia \& Suparmun, 2018), (Pattiasina, Tammubua, Numberi, Patiran, \& Temalagi, 2019), dan (Salawu \& Adedeji, 2017) yang menunjukkan bahwa kepemiikan institusional berpengaruh terhadap perencanaan pajak.

\section{H1 : Kepemilikan Institusional berpengaruh terhadap Perencanaan Pajak}

\section{Proporsi Dewan Komisaris Independen terhadap Perencanaan Pajak}

Komisaris Independen bersumber dari dewan komisaris yang berasal dari luar perusahaan publik serta memenuhi persyaratan sebagai komisaris independen sebagaimana dimaksud dalam Peraturan Otoritas Jasa Keuangan Nomor 33/POJK.04/2014. Keberadaan Komisaris Independen diharapkan dapat menciptakan objektivitas dan independen serta menjaga keadlian dan memberikan keseimbangan antara kepentingan pemegang saham mayoritas dan perlindungan terhadap kepentingan pemegang saham minoritas, bahkan kepentingan para stakeholders lainnya (Kuswiratmo, 2016).

Adanya dewan komisaris independen diharapkan dapat terjadi harmoni antara manajemen perusahaan dengan pemangku kepentingan perusahaan. Dewan komisaris independen diharapkan dapat melakukan pengawasan dan pengendalian yang baik terkait dengan pengelolaan perusahaan sesuai peraturan dan ketentuan yang berlaku yang dilakukan oleh manajemen perusahaan. Hal ini mengindikasi bahwa semakin besar proporsi dewan komisaris independent, maka tindakan perencanaan pajak yang dilakukan perusahaan akan semakin menurun. Berdasarkan peneltitian terdahulu yang dilakukan oleh (Prasetyo, Masitoh, \& Wijayanti, 2018), (Rosidy \& Nugroho, 2019), (Gunawan, Christy, Tin, \& Jonathan, 2021), (Mappadang, 2021), dan (Alfina, Nurlaela, \& Wijayanti, 2018) menunjukkan bahwa komisaris independen mempengaruhi tindakan perencanaan pajak di suatu perusahaan.

\section{H2 : Proporsi Dewan Komisaris Independen berpengaruh terhadap Perencanaan Pajak}

\section{Komite Audit terhadap Perencanaan Pajak}

Ikatan Komite Audit Indonesia (IKAI) menjelaskan bahwa komite audit merupakan sebuah komite bekerja secara professional dan independen serta dibentuk oleh dewan komisaris. Dengan demikian, tugas dari komite audit adalah membantu dewan komisaris atau dewan pengawas serta menguatkan dewan komisaris dalam menjalankan fungsinya dalam melakukan pengawasan (oversight) terhadap kegiatan pelaporan keuangan, proses audit, manajemen resiko dan pelaksanaan tata kelola di perusahaan (Effendi, 2016). Tanggung jawab utama komite audit dalam mewujudkan konsep Good Corporate governance adalah melakukan pemeriksaan dan pengawasan tentang proses pelaporan keuangan.

Jumlah komite audit yang semakin banyak dalam perusahaan akan meminimalisasi perencanaan pajak perusahaan. Karena Komite audit bertugas malakukan control dalam proses 
Owner: Riset \& Jurnal Akuntansi

e-ISSN : 2548-9224 | p-ISSN : 2548-7507

Volume 6 Nomor 1, Januari 2022

DOI : https://doi.org/10.33395/owner.v6i1.567

penyusunan laporan keuangan perusahaan umtuk menghindari kecurangan yang dilakukan pihak manajemen. Berdasarkan penelitian terdahulu yang dilakukan oleh (Waluyo, 2017), (Arismajayanti \& Jati, 2017), (Ayem \& Setyadi, 2019), (Idzniah \& Bernawati, 2020), dan (Fauzan, Wardan, \& Nurharjanti, 2019) ditemukan bahwa komite audit berpengaruh terhadap perencanaan pajak perusahaan.

\section{H3 : Komite Audit berpengaruh terhadap Perencanaan Pajak}

\section{Dewan Direksi terhadap Perencanaan Pajak}

Dewan direksi adalah orang yang bertanggung jawab untuk mengurus perusahaan. Peraturan Otoritas Jasa Keuangan No. 33/POJK.04/2014 tentang Direksi dan Dewan Komisaris Emiten menyebutkan bahwa Dewan Direksi dalam perusahaan terdiri dari minimal 2 (dua) orang anggota direksi. Dewan Direksi harus mengelola perusahaan berdasarkan kepentingan terbaik dari perusahaan dan pemegang saham. Perlu diyakini bahwa perusahaan telah melaksanakan tanggungjawab sosialnya (misalnya bertindak sebagai warga negara yang baik di negara dimana perusahaan melakukan usaha) dan mempertimbangkan kepentingan dari berbagai stakeolder (Tunggal, 2016).

Dewan direksi bertugas untuk mengelola manajemen perusahaan dalam melakukan operasional perusahaan agar berjalan efektif dan efisien. Permasalahan keagenan yang terjadi didalam perusahaan dapat diminimumkan dengan adanya kehadiran dewan direksi. Semakin banyaknya jumlah dewan direksi maka akan mengurangi tindakan manajemen untuk melakukan perencanaan pajak. Berdasarkan penelitian terdahulu yang dilakukan oleh (Prasetyo, Masitoh, \& Wijayanti, 2018), (Salawu \& Adedeji, 2017), (Idzniah \& Bernawati, 2020), (Egbunike, Gunardi, Ugochukwu, \& Hermawan, 2021), dan (Imuetinyan, Solomon, \& Jonathan, 2019)menunjukkan bahwa dewan direksi berpengaruh terhadap perencanaan pajak yang dilakukan perusahaan.

\section{H4 : Dewan Direksi berpengaruh terhadap Perencanaan Pajak}

\section{Solvabilitas terhadap Perencanaan Pajak}

Rasio solvabilitas merupakan rasio yang digunakan untuk mengukur besarnya aktiva perusahaan dibiayai oleh utang perusahaan. Artinya rasio ini mengukur seberapa besar perusahaan menggunakan jumlah utang dibandingkan dengan menggunakan modal sendiri dalam membiayai kegiatan usahanya. Besar kecilnya nilai dari rasio ini tergantung dari sebera besar pinjaman yang dilakukan perusahaan, dibandingkan dengan aktiva yang dimilikinya (ekuitas) (Kasmir, 2015).

Nilai solvabilitas yang tinggi mengindikasi bahwa perusahaan memiliki utang yang besar. Akibatnya, perusahaan memiliki beban yang timbul dari utang tersebut yaitu beban bunga pinjaman dimana beban bunga tersebut akan mengurangi laba perusahaan. Berkurangnya laba perusahaan berarti berkurangnya pembayaran pajak, sehingga tindakan perencanaan pajak yang mungkin dilakukan manajemen akan menurun. Pernyataan ini didukung oleh penelitian yang dilakukan oleh (Putri, Setiawan, Faishol, Roza, \& Yudha, 2018), (Dias \& Reis, 2018), (Salaudeen \& Ejeh, 2018), (Hazir, 2019) dan (Pangaribuan, HB, Agoes, Sihombing, \& Sunarsi, 2021) ditemukan bahwa solvabilitas berpengaruh terhadap perencanaan pajak perusahaan.

\section{H5 : Solvabilitas berpengaruh terhadap Perencanaan Pajak}

\section{Profitabilitas terhadap Perencanaan Pajak}

Rasio Profitabilitas merupakan rasio untuk menilai kemampuan perusahaan dalam mencari keuntungan atau laba dalam suatu periode tertentu. Rasio ini juga memberikan ukuran tingkat efektivitas manajemen suatu perusahaan yang ditunjukkan dari laba yang dihasilkan dari penjualan atau dari pendapatan investasi. Dikatakan perusahaan profitabilitasnya baik apabila mampu memenuhi target laba yang telah ditetapkan dengan menggunakan aktiva atau modal yang dimilikinya (Kasmir, 2015).

Laba yang dihasilkan akan berbanding lurus dengan beban pajak perusahaan. Dengan adanya beban pajak tersebut akan memotivasi manajemen perusahaan untuk melakukan perencanaan 
Owner: Riset \& Jurnal Akuntansi

e-ISSN : 2548-9224 | p-ISSN : 2548-7507

Volume 6 Nomor 1, Januari 2022

DOI : https://doi.org/10.33395/owner.v6i1.567

pajak. Perencanaan pajak dilakukan agar pembayaran pajak tidak terlalu tinggi. Sehingga, pajak yang dibayarkan rendah dan profit perusahaan akan tetap tinggi. Pernyataan ini didukung dengan hasil penelitian terdahulu yang dilakukan oleh (Dias \& Reis, 2018), (Putri, Setiawan, Faishol, Roza, \& Yudha, 2018), (Sonia \& Suparmun, 2018), (Hazir, 2019) dan (Pangaribuan, HB, Agoes, Sihombing, \& Sunarsi, 2021).

\section{H6 : Profitabilitas berpengaruh terhadap Perencanaan Pajak}

\section{Ukuran Perusahaan terhadap Perencanaan Pajak}

Ukuran perusahaan dapat diukur dengan total aset ataupun total penjualan bersih. Dalam penelitian ini, ukuran perusahaan diukur menggunakan total aset. Semakin besar total aset maka ukuran perusahaan dapat dinyatakan semakin besar. Semakin besar aset menunjukkan semakin besar modal yang ditanam di perusahaan (Hery, 2017).

Perusahaan dengan skala besar cenderung memiliki peluang lebih besar untuk perencanaan pajak yang baik dan mengadopsi praktik dan metode akuntansi yang efektif untuk menurunkan tarif efektifnya. Teori agensi menyatakan bahwa semakin besar ukuran sebuah perusahaan, maka semakin besar juga biaya keagenan yang muncul. Agar biaya keagenan dapat menurun, perusahaan akan berusaha mengungkapkan informasi dengan lebih luas. Dengan adanya biaya tersebut akan mengurangi laba perusahaan, sehingga pajak yang harus dibayarkan perusahaan juga semakin kecil. Hal ini akan mengakitbakan tindakan perencanaan pajak perusahaan menurun. Pernyataan ini didukung dengan penelitian yang dilakukan oleh (Irianto, Sudibyo, \& Wafirli, 2017), (Dias \& Reis, 2018), (Aburajab, Maali, Jaradat, \& Alsharairi, 2019), (Hazir, 2019), dan (Chytis, Taslos, \& Filos, 2020) menyatakan bahwa ukuran perusahaan berpengaruh terhadap perencanaan pajak yang dilakukan perusahaan.

\section{H7 : Ukuran Perusahaan berpengaruh terhadap Perencanaan Pajak}

\section{Peluang Pertumbuhan terhadap Perencanaan Pajak}

Peluang pertumbuhan dalam penelitian ini diproksikan dengan pertumbuhan penjualan. Pertumbuhan penjualan adalah kenaikan penjualan dari tahun ini dibandingkan dengan tahun lalu. Pertumbuhan Penjualan digunakan untuk mengukur seberapa besar kemampuan perusahaan dalam mempertahankan posisinya di dalam industri dan dalam perkembangan ekonomi secara umum. Perusahaan yang mempunyai volume penjualan dalam unit yang besar mempunyai pendapatan yang relatif lebih stabil bila dibandingkan dengan perusahaan yang unit penjualannya kecil (Jumingan, 2014)..

Pertumbuhan penjualan yang semakin meningkat menyebabkan aktivitas penghindaran pajak suatu perusahaan semakin rendah karena perusahaan dengan tingkat penjualan yang relatif besar memiliki kecukupan modal kerja yang tidak akan mengganggu operasional perpajakan serta pertumbuhan penjualan yang meningkat akan berdampak terhadap peningkatan laba yang diperoleh perusahaan sehingga perusahaan mampu untuk melakukan pembayaran pajak. Penelitian yang dilakukan oleh (Januari \& Suardikha, 2019), (Kim \& Im, 2017), (Pangaribuan, HB, Agoes, Sihombing, \& Sunarsi, 2021), (Fauzan, Wardan, \& Nurharjanti, 2019), dan (Putri, Azmi, \& Arsa, 2021) membuktikan bahwa peluang pertumbuhan mampu mempengaruhi tindakan perencanaan pajak yang dilakukan perusahaan.

\section{H8 : Peluang Pertumbuhan berpengaruh terhadap Perencanaan Pajak}

\section{Capital Intensity Ratio}

Dalam Penelitian ini capital intensity ratio diproksikan dengan rasio intensitas asset tetap. Intensitas asset tetap menggambarkan seberapa banyak asset perusahaan yang diinvestasikan dalam bentuk asset tetap (Putra, Yuliusman, \& Wisra, 2020). Pemilihan investasi oleh manajemen dalam bentuk asset tetap sangat terkait dengan hal perpajakan. Jika manajemen perusahaan meningkatkan investasi dalam bentuk asset tetap maka mengakibatkan jumlah penghasilan kena pajak dan tarif pajak efektifnya semakin kecil. 
Owner: Riset \& Jurnal Akuntansi

e-ISSN : 2548-9224 | p-ISSN : 2548-7507

Volume 6 Nomor 1, Januari 2022

DOI : https://doi.org/10.33395/owner.v6i1.567

Sebagian besar aset tetap akan mengalami penyusutan dan menghasilkan biaya penyusutan. Biaya penyusutan akan menekan jumlah pajak yang dibayar perusahaan. Beban penyusutan yang terjadi akan menjadi pengurang laba di akhir periode akuntansi. Sehingga, perencanaan pajak sangat mungkin terjadi dengan memanfaatkan pemilihan metode akuntansi. Pernyataan ini didukung dengan hasil penelitian yang dilakukan oleh (Hazir, 2019), (Kim \& Im, 2017), (Nuryatun \& Mulyani, 2020), (Santini \& Indrayani, 2020), dan (Ayem \& Setyadi, 2019) menyatakan bahwa capital intensity ratio berpengaruh terhadap perencanaan pajak yang dilakukan perusahaan.

\section{H9 : Capital Intensity Ratio berpengaruh terhadap Perencanaan Pajak}

Berdasarkan studi literatur dan hipotesis yang diajukan dalam penelitian ini maka, kerangka konseptual dari penelitian ini adalah:

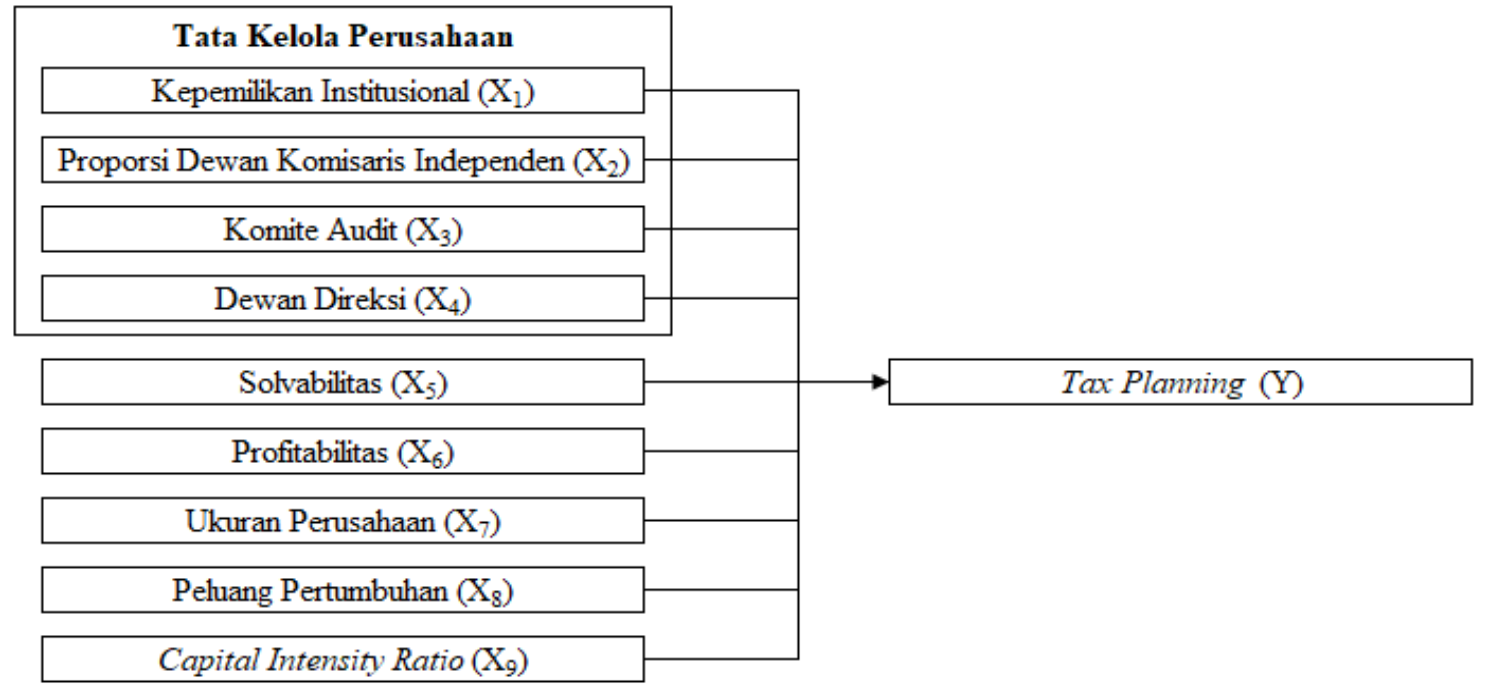

Gambar 2 Kerangka Konseptual Penelitian

\section{Jenis Penelitian}

METODE

Penelitian ini merupakan penelitian asosiatif kausal yang bertujuan untuk mengetahui hubungan antara dua variabel atau lebih dengan menggunakan data kuantitatif (Sugiyono, 2016). Populasi dalam penelitian ini adalah Perusahaan Pertambangan yang terdaftar di Bursa Efek Indonesia. Untuk memperoleh data Penelitian, laporan keuangan di unduh dari situs resmi Bursa Efek Indonesia yaitu www.idx.co.id selama periode 2015 -2018.

\section{Populasi dan Sampel}

Penelitian ini menggunakan teknik penarikan sampel purposive sampling dengan kriteria; (1) Perusahaan pertambangan yang secara konsisten terdaftar di Bursa Efek Indonesia selama periode pengamatan, (2) Perusahaan pertambangan yang memiliki laba dan pajak terutang secara konsisten selama periode pengamatan, (3) Perusahaan pertambangan yang memiliki proporsi kepemilikan institusional secara konsisten selama periode pengamatan. Jumlah sampel yang diperoleh adalah sebanyak 11 perusahaan dengan jumlah data observasi sebanyak 44.

\section{Tabel 1 Sampel Penelitian}

\begin{tabular}{|c|c|c|}
\hline No & Kode Emiten & Nama Emiten \\
\hline 1 & ADRO & PT Adaro Energy Tbk. [S] \\
\hline 2 & BSSR & PT Baramulti Suksessarana Tbk. [S] \\
\hline 3 & CTTH & PT Citatah Tbk. [S] \\
\hline
\end{tabular}


Owner: Riset \& Jurnal Akuntansi

e-ISSN : 2548-9224 | p-ISSN : 2548-7507

Volume 6 Nomor 1, Januari 2022

DOI : https://doi.org/10.33395/owner.v6i1.567

\begin{tabular}{|c|c|c|}
\hline 4 & DEWA & PT Darma Henwa Tbk. [S] \\
\hline 5 & ELSA & PT Elnusa Tbk. [S] \\
\hline 6 & ITMG & PT Indo Tambangraya Megah Tbk. [S] \\
\hline 7 & KKGI & PT Resource Alam Indonesia Tbk. [S] \\
\hline 8 & MYOH & PT Samindo Resources Tbk. [S] \\
\hline 9 & RUIS & PT Radiant Utama Interinsco Tbk. [S] \\
\hline 10 & TINS & PT Timah (Persero) Tbk. [S] \\
\hline 11 & TOBA & PT Toba Bara Sejahtra Tbk. [S] \\
\hline
\end{tabular}

\section{Definisi Operasional Variabel}

\section{Tabel 2 Definisi Operasional Variabel}

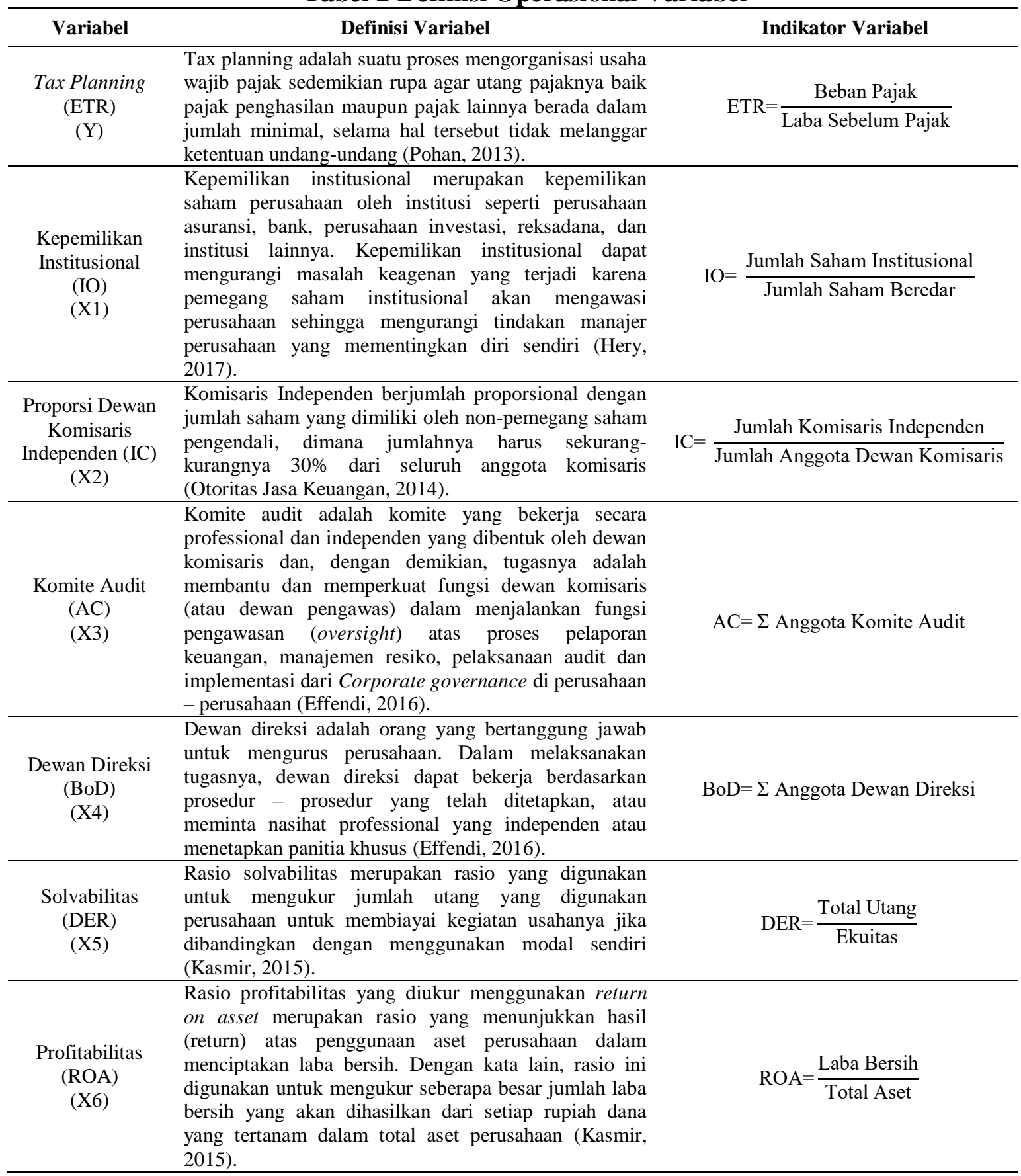


Owner: Riset \& Jurnal Akuntansi

e-ISSN : 2548-9224 | p-ISSN : 2548-7507

Volume 6 Nomor 1, Januari 2022

DOI : https://doi.org/10.33395/owner.v6i1.567

\begin{tabular}{|c|c|c|}
\hline Variabel & Definisi Variabel & Indikator Variabel \\
\hline $\begin{array}{l}\text { Ukuran } \\
\text { Perusahaan } \\
\text { (Size) } \\
\text { (X7) }\end{array}$ & $\begin{array}{l}\text { Ukuran perusahaan menjelaskan besar atau kecilnya } \\
\text { suatu perusahaan. Ukuran perusahaan dapat dinyatakan } \\
\text { dengan total aset ataupun total penjualan bersih. } \\
\text { Semakin besar total aset maupun penjualan maka } \\
\text { semakin besar pula ukuran suatu perusahaan (Hery, } \\
\text { 2017). }\end{array}$ & Size $=\ln ($ Total Aset $)$ \\
\hline $\begin{array}{l}\text { Peluang } \\
\text { Pertumbuhan } \\
\text { (SG) } \\
\text { (X8) }\end{array}$ & $\begin{array}{l}\text { Peluang pertumbuhan merupakan peluang untuk } \\
\text { mencapai tingkat pertumbuhan yang tinggi atau } \\
\text { peluang untuk mengembangkan perusahaannya. } \\
\text { Pertumbuhan sebuah perusahaan merupakan hal yang } \\
\text { paling penting karena menentukan keberlangsungan } \\
\text { perusahaan di masa mendatang (Zaini, 2016). }\end{array}$ & $\mathrm{SG}=\frac{\text { Penjualan }_{\mathrm{t}}-\text { Penjualan }_{\mathrm{t}-1}}{\text { Penjualan }_{\mathrm{t}-1}}$ \\
\hline $\begin{array}{c}\text { Capital } \\
\text { Intensity Ratio } \\
\text { (CIR) } \\
\text { (X9) }\end{array}$ & $\begin{array}{l}\text { Capital intensity ratio didefinisikan sebagai seberapa } \\
\text { besar perusahaan menginvestasikan asetnya pada asset } \\
\text { tetap dan persediaan. Dalam Penelitian ini capital } \\
\text { intensity ratio akan diproksikan dengan rasio intensitas } \\
\text { asset tetap. Intensitas asset tetap menggambarkan } \\
\text { seberapa banyak asset perusahaan yang diinvestasikan } \\
\text { dalam bentuk asset tetap (Putra, Yuliusman, \& Wisra, } \\
\text { 2020). }\end{array}$ & $\mathrm{CIR}=\frac{\text { Total Net Fixed Assets }}{\text { Total Assets }} \times 100 \%$ \\
\hline
\end{tabular}

\section{Metode Analisis data}

Dalam penelian ini digunakan metode analisis data yaitu analisis statistik dengan bantuan program SPSS 21. Peneliti menggunakan metode confirmatory factor analysis untuk mengetahui variabel-variabel independen yang memiliki korelasi yang cukup. Setelah itu Penelitian melakukan pengujian asumsi klasik terhadap data-data yang digunakan, dan dilanjutkan dengan analisis regresi berganda. Dalam melakukan uji hipotesis digunakan model Penelitian sebagai berikut (Ghozali, 2013):

Keterangan:

$$
\mathrm{Y}=\alpha+\beta \mathrm{iXi}+e
$$

Y : Tax Planning

$\alpha$ : Konstanta

$\beta i$ : Koefisien regresi variabel independen

$\mathrm{Xi}$ : Variabel Independen

e: Error

HASIL

Gambaran statistik deskriptif atas data Penelitian dijelaskan pada Tabel 2 berikut:

Tabel 3 Statistik Deskriptif

\begin{tabular}{|l|r|r|r|}
\hline \multicolumn{1}{|c|}{ Variabel } & \multicolumn{1}{c|}{ Min } & \multicolumn{1}{c|}{ Max } & \multicolumn{1}{c|}{ Mean } \\
\hline Tax_Planning (Y) & .215 & .914 & .38224 \\
\hline Institutional_Ownership (X1) & .260 & .933 & .59674 \\
\hline Proportion_indepen_com (X2) & .200 & .667 & .37397 \\
\hline Audit_Committee (X3) & 3.000 & 5.000 & 3.13636 \\
\hline Board_Directors (X4) & 3.000 & 8.000 & 5.15909 \\
\hline Solvency (X5) & .169 & 2.226 & .76540 \\
\hline Profitability (X6) & .001 & .394 & .08115 \\
\hline Firm_Size (X7) & 27.130 & 37.202 & 29.33081 \\
\hline Growth_Oppurtunity (X8) & -.320 & .618 & .04354 \\
\hline Capital_Intensity_Ratio (X9) & .096 & .453 & .28711 \\
\hline
\end{tabular}

Sumber: Data diolah peneliti (2021) 
Owner: Riset \& Jurnal Akuntansi

e-ISSN : 2548-9224 | p-ISSN : 2548-7507

Volume 6 Nomor 1, Januari 2022

DOI : https://doi.org/10.33395/owner.v6i1.567

Tabel 4 CFA Anti-Image Correlation Matrix

\begin{tabular}{|c|c|c|c|c|c|c|c|c|c|}
\hline & $\mathrm{X} 1$ & $\mathrm{X} 2$ & $\mathrm{X} 3$ & $\mathrm{X} 4$ & $\mathrm{X} 5$ & $\mathrm{X} 6$ & $\mathrm{X} 7$ & $\mathrm{X} 8$ & $\mathrm{X} 9$ \\
\hline $\mathrm{X} 1$ & $\mathbf{0 , 4 2 3}$ & $-0,388$ & $-0,378$ & 0,342 & 0,102 & $-0,681$ & 0,184 & 0,167 & 0,602 \\
\hline $\mathrm{X} 2$ & $-0,388$ & $\mathbf{0 , 4 2 7}$ & 0,458 & $-0,012$ & $-0,010$ & 0,342 & 0,037 & 0,235 & 0,028 \\
\hline $\mathrm{X} 3$ & $-0,378$ & 0,458 & $\mathbf{0 , 2 2 2}$ & $-0,091$ & $-0,052$ & 0,422 & $-0,047$ & $-0,032$ & $-0,016$ \\
\hline $\mathrm{X} 4$ & 0,342 & $-0,012$ & $-0,091$ & $\mathbf{0 , 5 5 4}$ & 0,425 & $-0,402$ & $-0,148$ & 0,134 & 0,515 \\
\hline $\mathrm{X} 5$ & 0,102 & $-0,010$ & $-0,052$ & 0,425 & $\mathbf{0 , 7 5 8}$ & 0,085 & $-0,079$ & $-0,132$ & 0,030 \\
\hline $\mathrm{X} 6$ & $-0,681$ & 0,342 & 0,422 & $-0,402$ & 0,085 & $\mathbf{0 , 4 3 6}$ & 0,045 & $-0,415$ & $-0,353$ \\
\hline $\mathrm{X} 7$ & 0,184 & 0,037 & $-0,047$ & $-0,148$ & $-0,079$ & 0,045 & $\mathbf{0 , 5 7 2}$ & $-0,131$ & 0,218 \\
\hline X8 & 0,167 & 0,235 & $-0,032$ & 0,134 & $-0,132$ & $-0,415$ & $-0,131$ & $\mathbf{0 , 5 3 5}$ & 0,162 \\
\hline X9 & 0,602 & 0,028 & $-0,016$ & 0,515 & 0,030 & $-0,353$ & 0,218 & 0,162 & $\mathbf{0 , 5 3 0}$ \\
\hline
\end{tabular}

Sumber: Data diolah peneliti (2021)

Berdasarkan hasil uji Anti-Image Correlation Matrix untuk seluruh variabel independen, ditemukan bahwa variabel komite audit tidak memenuhi persyaratan uji $(<0,3)$ sehingga dikeluarkan dari model penelitian yang kemudian akan dilanjutkan ke pengujian regresi berganda dan selanjutnya ke pengujian hasil.

Tabel 5 Hasil Uji Faktor Measure of Sampling Adequacy

\begin{tabular}{|l|l|r|}
\hline Kaiser-Meyer-Olkin Measure of Sampling Adequacy. & .537 \\
\hline \multirow{3}{*}{ Bartlett's Test of Sphericity } & Approx. Chi-Square & 111.649 \\
\cline { 2 - 3 } & df & 28 \\
\cline { 2 - 3 } & Sig. & .000 \\
\hline
\end{tabular}

Sumber Tabel: Data diolah (2021)

Berdasarkan Tabel 4, dapat terlihat bahwa nilai Measure of Sampling Adequacy 0,537 > 0,5 yang berarti variabel independen yang digunakan dapat dilanjutkan untuk pengujian regresi berganda. Hasil pengujian hipotesis dapat dilihat pada tabel 3:

Tabel 6 Hasil Pengujian Hipotesis

\begin{tabular}{|l|c|c|c|c|c|}
\hline \multirow{2}{*}{ Model } & \multicolumn{2}{|c|}{$\begin{array}{c}\text { Unstandardized } \\
\text { Coefficients }\end{array}$} & $\begin{array}{c}\text { Standardized } \\
\text { Coefficients }\end{array}$ & \multirow{2}{*}{ Sig. } & \\
\cline { 2 - 5 } & $\mathrm{B}$ & $\begin{array}{c}\text { Std. } \\
\text { Error }\end{array}$ & Beta & & \\
\hline Constant) & -3.262 & .843 & & -3.872 & .001 \\
\hline Kepemilikan Institusional & -.418 & .136 & -.411 & -3.069 & .005 \\
\hline Proporsi Dewan Komisaris Independen & .008 & .502 & .002 & .016 & .987 \\
\hline Dewan Direksi & -.004 & .036 & -.016 & -.114 & .910 \\
\hline Solvabilitas & -.054 & .080 & -.086 & -.677 & .504 \\
\hline Profitabilitas & -.167 & .034 & -.640 & -4.963 & .000 \\
\hline Ukuran Perusahaan & .038 & .031 & .158 & 1.241 & .225 \\
\hline Peluang Pertumbuhan & -.452 & .195 & -.258 & -2.313 & .028 \\
\hline Capital Intensity Ratio & -.256 & .122 & -.290 & -2.094 & .045 \\
\hline
\end{tabular}

Sumber Tabel: Data diolah (2021)

Berdasarkan tabel 3, hasil persamaan regresi linier berganda yang terbentuk adalah:

ln_Perencanaan Pajak $=-3,262-0,418$ ln_Kepemilikan Institusional + 0,008 Proporsi Dewan

Komisaris Independen - 0,004 Dewan Direksi - 0,054 ln_Solvabilitas 0,167 ln_Profitabilitas $+0,038$ Ukuran_Perusahaan $-0,452$ Peluang_Pertumbuhan - 0,256 ln_Capital Intensity Ratio 
Owner: Riset \& Jurnal Akuntansi

e-ISSN : 2548-9224 | p-ISSN : 2548-7507

Volume 6 Nomor 1, Januari 2022

DOI : https://doi.org/10.33395/owner.v6i1.567

\section{PEMBAHASAN \\ Dampak Kepemilikan Institusional terhadap Perencanaan Pajak}

Dari hasil Penelitian diperoleh bahwa Kepemilikan Institusional memiliki pengaruh negatif dan signifikan terhadap tindakan Perencanaan Pajak. Hasil penelitian ini sejalan dengan penelitian terdahulu yang menyatakan proporsi Kepemilikan Institusional akan mempengaruhi tindakan Perencanaan Pajak yang dilakukan perusahaan (Khan, Srinivasan, \& Tan, 2017) (Putra, Yuliusman, \& Wisra, 2020) (Sonia \& Suparmun, 2018) (Pattiasina, Tammubua, Numberi, Patiran, \& Temalagi, 2019) (Salawu \& Adedeji, 2017). Namun, hasil penelitian ini bertolak belakang dengan penelitian lainnya yang menyatakan bahwa Kepemilikan Institusional tidak mempengaruhi tindakan Perencanaan Pajak yang dilakukan perusahaan (Putri, Setiawan, Faishol, Roza, \& Yudha, 2018) (Waluyo, 2017) (Salaudeen \& Ejeh, 2018) (Jamei, 2017) (Chytis, Taslos, \& Filos, 2020).

Kepemilikan Institusional berpengaruh negatif signifikan terhadap perencanaan pajak yang berarti apabila proporsi kepemilikan institusional semakin tinggi, maka tarif pajak efektif perusahaan akan semakin rendah yang menandakan bahwa perusahaan melakukan tindakan perencanaan pajak. Adanya kepemilikan institusional yang tinggi di dalam suatu perusahaan diharapkan dapat menciptakan kontrol pengawasan yang lebih baik dikarenakan banyaknya pihak eksternal yang turut mengawasi kinerja perusahaan. Para investor umumnya hanya terfokus pada kemampuan perusahaan dalam menghasilkan laba yang tinggi, jika perusahaan tersebut mampu menghasilkan laba yang tinggi maka investor akan menilai baik kinerja manajemen perusahaan. Pajak merupakan salah satu beban yang jumlahnya dapat dengan signifikan menurunkan jumlah laba yang dihasilkan oleh perusahaan dan akan menyebabkan laba yang dapat didistribusikan untuk para pemegang saham menurun. Ketika laba perusahaan menurun maka kinerja manajemen perusahaan akan dinilai kurang baik oleh para investor institusional, sehingga manajemen perusahaan akan berupaya untuk melakukan tindakan perencanaan pajak dengan mengurangi beban pajak yang ditanggung dengan cara seperti melakukan tax saving atau dengan mengoptimalkan kredit pajak agar laba yang dihasilkan bisa lebih banyak didistribusikan untuk investor institusional.

\section{Dampak Proporsi Dewan Komisaris Independen terhadap Perencanaan Pajak}

Hasil penelitian menunjukkan bahwa variabel Proporsi Dewan Komisaris Independen tidak berpengaruh terhadap Perencanaan Pajak. Hasil ini mendukung penelitian terdahulu yang menyatakan bahwa Proporsi Dewan Komisaris Independen tidak mempengaruhi Perencanaan Pajak (Sonia \& Suparmun, 2018) (Pattiasina, Tammubua, Numberi, Patiran, \& Temalagi, 2019) (Arismajayanti \& Jati, 2017). Namun, hasil penelitian ini bertolak belakang dengan penelitian lainnya yang menyatakan bahwa Proporsi Dewan Komisaris Independen mempengaruhi Perencanaan Pajak (Prasetyo, Masitoh, \& Wijayanti, 2018).

Dewan komisaris independen bertugas mengawasi kebijakan manajemen dan mengawasi pelaksanaan rencana jangka panjang perusahaan. Keberadaan dewan komisaris independen diharapkan dapat menciptakan keharmonisan antara manajemen perusahaan dengan para pemangku kepentingan perusahaan. Proporsi komisaris independen yang tinggi akan meminimalkan tindakan manajemen melakukan perencanaan pajak dalam pelaporan pajak perusahaan sehingga akan meningkatkan nilai informasi keuangan perusahaan. Oleh karena itu, semakin besar proporsi komisaris independen dalam suatu perusahaan, maka akan menurunkan praktik perencanaan pajak di perusahaan menurun.

Dalam penelitian ini proporsi komisaris independen tidak mempengaruhi tindakan manajemen melakukan perencanaan pajak. Hasil ini menandakan bahwa tinggi rendahnya proporsi komisaris independen tidak mempengaruhi perusahaan dalam kegiatan perencanaan pajak. Faktor yang mungkin menjadi faktor tinggi rendahnya komisaris independen tidak mampu mempengaruhi tindakan perencanaan pajak perusahaan pertama, dikarenakan komisaris independen hanya dapat mengawasi kinerja dan rencana manajemen perusahaan, sementara pengambilan keputusan tetaplah merupakan kewenangan manajemen perusahaan. Selain itu, adanya keterbatasan kemampuan 
Owner: Riset \& Jurnal Akuntansi

e-ISSN : 2548-9224 | p-ISSN : 2548-7507

Volume 6 Nomor 1, Januari 2022

DOI : https://doi.org/10.33395/owner.v6i1.567

komisaris independen dalam rangka memantau proses keterbukaan dan penyediaan informasi karena pihak-pihak yang memiliki hubungan di perusahaan lebih mendominasi dan dapat mengendalikan sehingga dewan komisaris independen kurang tanggap dalam memperhatikan perencanaan pajak perusahaan.

\section{Dampak Dewan Direksi terhadap Perencanaan Pajak}

Hasil penelitian menunjukkan bahwa variabel Dewan Direksi tidak mempengaruhi Perencanaan Pajak. Hasil penelitian ini mendukung hasil penelitian terdahulu yang menyatakan bahwa Dewan Direksi tidak mempengaruhi terhadap Perencanaan Pajak (Jamei, 2017) (Chytis, Taslos, \& Filos, 2020). Namun, penelitian ini berbeda dengan hasil penelitian lainnya yang menyatakan bahwa Dewan Direksi mempengaruhi tindakan perusahaan melakukan Perencanaan Pajak (Prasetyo, Masitoh, \& Wijayanti, 2018) (Salawu \& Adedeji, 2017).

Dewan direksi merupakan tingkatan tertinggi di dalam manajemen perusahaan dan memegang peranan utama dalam tatakelola perusahaan karena memiliki tanggungjawab legal untuk mengelola manajemen perusahaan agar berjalan efektif dan efisien. Permasalahan keagenan yang terjadi didalam perusahaan dapat diminimalkan dengan adanya kehadiran dewan direksi. Semakin banyaknya jumlah dewan direksi maka akan mengurangi tindakan manajemen untuk melakukan perencanaan pajak.

Dalam penelitian ini, dewan direksi tidak mempengaruhi perencanaan pajak. Hasil ini menjelaskan bahwa jumlah dewan direksi tidak mempengaruhi perusahaan dalam melakukan perencanaan pajak. Hal ini mungkin terjadi karena peran dewan direksi yang berfokus dalam mengelola perusahaan agar berjalan efektif dan efisien sehingga akan lebih terpusat kepada operasional perusahaan daripada ke kualitas laporan keuangan. Sehingga, jumlah anggota dewan direksi yang besar atau kecil tidak mempengaruhi praktik perencanaan pajak yang mungkin dilakukan perusahaan.

\section{Dampak Solvabilitas terhadap Perencanaan Pajak}

Hasil penelitian menunjukkan bahwa variabel Solvabilitas tidak mempengaruhi Perencanaan Pajak. Hasil penelitian ini sejalan dengan penelitian terdahulu yang menyatakan bahwa Solvabilitas tidak mempengaruhi Perencanaan Pajak (Prasetyo, Masitoh, \& Wijayanti, 2018) (Sonia \& Suparmun, 2018) (Chytis, Taslos, \& Filos, 2020). Namun, hasil penelitian ini bertolak belakang dengan Penelitian lainnya yang menyatakan bahwa Solvabilitas mempengaruhi Perencanaan Pajak (Putri, Setiawan, Faishol, Roza, \& Yudha, 2018) (Hazir, 2019) (Dias \& Reis, 2018) (Salaudeen \& Ejeh, 2018) (Arismajayanti \& Jati, 2017) (Pangaribuan, HB, Agoes, Sihombing, \& Sunarsi, 2021).

Solvabilitas merupakan kebijakan pendanaan dalam membiayai kegiatan operasional dalam perusahaan. Perusahaan dapat menggunakan utang sebagai salah satu sumber pendanaannya. Jumlah utang yang bertambah akan menimbulkan beban bunga yang bertambah pula. Beban bunga tersebut akan menjadi salah satu unsur pengurang laba kena pajak perusahaan sehingga pajak yang dibayarkan akan menjadi turun. Perusahaan yang menggunakan sumber pendanaan dalam bentuk utang akan memiliki laba kena pajak yang lebih kecil dibandingkan perusahaan yang menggunakan sumber dana lainnya seperti dari saham. Sehingga kebijakan pendanaan dengan utang ini digolongkan sebagai salah satu cara perusahaan untuk melakukan perencanaan pajak.

Dalam penelitian ini, solvabilitas tidak mempengaruhi perencanaan pajak. Tidak berpengaruhnya solvabilitas terhadap perencanaan pajak dikarenakan perusahaan yang menjadi objek pengamatan penelitian ini tidak memanfaatkan utang untuk meminimalkan beban pajak. Namun penggunaan utang dilakukan untuk berinvestasi jangka panjang sehingga tidak menimbulkan beban bunga pada setiap periode laporan keuangan. Hal ini lah yang menyebabkan tingkat solvabilitas perusahaan tidak berpengaruh terhadap praktik perencanaan pajak yang dilakukan perusahaan. 
Owner: Riset \& Jurnal Akuntansi

e-ISSN : 2548-9224 | p-ISSN : 2548-7507

Volume 6 Nomor 1, Januari 2022

DOI : https://doi.org/10.33395/owner.v6i1.567

\section{Dampak Profitabilitas terhadap Perencanaan Pajak}

Hasil penelitian menunjukkan bahwa Profitabilitas berpengaruh negatif dan signifikan terhadap Perencanaan Pajak. Hasil penelitian ini mendukung hasil penelitian terdahulu yang menyatakan bahwa Profitabilitas mempengaruhi Perencanaan Pajak (Putra, Yuliusman, \& Wisra, 2020) (Sonia \& Suparmun, 2018) (Putri, Setiawan, Faishol, Roza, \& Yudha, 2018) (Irianto, Sudibyo, \& Wafirli, 2017) (Dias \& Reis, 2018) (Salaudeen \& Ejeh, 2018) (Salawu \& Adedeji, 2017) (Pangaribuan, HB, Agoes, Sihombing, \& Sunarsi, 2021). Namun, hasil penelitian ini bertolak belakang dengan Penelitian lainnya yang menyatakan bahwa Profitabilitas tidak mempengaruhi Perencanaan Pajak (Prasetyo, Masitoh, \& Wijayanti, 2018) (Hazir, 2019).

Dalam penelitian ini, profitabilitas berpengaruh negatif signifikan terhadap perencanaan pajak. Pengaruh negatif ini menunjukkan tingkat profitabilitas yang semakin tinggi, maka tarif pajak efektif perusahaan semakin rendah yang menandakan bahwa perusahaan melakukan perencanaan pajak. Hal ini bisa disebabkan oleh adanya pengakuan pendapatan yang menambah laba perusahaan namun dialokasikan dalam pendapatan yang bukan merupakan objek pajak perusahaan. Sehingga, walaupun profitabilitas perusahaan meningkat tetapi pajak yang dibayarkan perusahaan rendah.

\section{Dampak Ukuran Perusahaan terhadap Perencanaan Pajak}

Hasil penelitian menunjukkan bahwa variabel Ukuran Perusahaan tidak mempengaruhi Perencanaan Pajak. Hasil penelitian ini sesuai dengan hasil penelitian terdahulu yang menyatakan bahwa Ukuran Perusahaan tidak mempengaruhi Perencanaan Pajak (Putri, Setiawan, Faishol, Roza, \& Yudha, 2018) (Salaudeen \& Ejeh, 2018). Namun, hasil penelitian ini bertolak belakang dengan penelitian lainnya yang menyatakan bahwa Ukuran Perusahaan mempengaruhi Perencanaan Pajak (Irianto, Sudibyo, \& Wafirli, 2017) (Hazir, 2019) (Aburajab, Maali, Jaradat, \& Alsharairi, 2019) (Dias \& Reis, 2018) (Chytis, Taslos, \& Filos, 2020) (Salawu \& Adedeji, 2017).

Perusahaan dengan skala besar akan mampu menggunakan sumber daya yang dimilikinya secara optimal dan akan memaksimalkan efisiensi pajak. Perusahaan besar cenderung memiliki peluang melakukan perencanaan pajak yang lebih besar karena mengadopsi praktek dan metode Akuntansi yang efektif untuk menurunkan tarif pajak efektif nya.

Dalam penelitian ini, ukuran perusahaan tidak berpengaruh terhadap perencanaan pajak. Objek penelitian ini adalah perusahaan publik yang di mana besar atau kecilnya skala perusahaan, informasi keuangan yang disajikan pasti akan menjadi perhatian publik. Sehingga, perusahaanperusahaan tersebut dituntut untuk melakukan pembayaran pajak sesuai dengan ketentuan perpajakan yang berlaku tanpa memperhatikan besaran ukuran perusahaannya sehingga tidak melakukan perencanaan pajak agar terhindar dari keraguan kredibilitas perusahaan di mata publik.

\section{Dampak Peluang Pertumbuhan terhadap Perencanaan Pajak}

Hasil penelitian menunjukkan bahwa Peluang Pertumbuhan berpengaruh negatif dan signifikan terhadap Perencanaan Pajak. Hasil penelitian ini mendukung hasil penelitian terdahulu yang menyatakan bahwa Peluang Pertumbuhan mempengaruhi terhadap Perencanaan Pajak (Januari \& Suardikha, 2019) (Kim \& Im, 2017) (Pangaribuan, HB, Agoes, Sihombing, \& Sunarsi, 2021). Namun, hasil penelitian ini bertolak belakang dengan penelitian lainnya yang menyatakan bahwa Peluang Pertumbuhan tidak mempengaruhi terhadap Perencanaan Pajak (Sonia \& Suparmun, 2018) (Salawu \& Adedeji, 2017).

Peluang pertumbuhan perusahaan berpengaruh negatif dan signifikan. Arah negatif pada hasil penelitian ini menjelaskan bahwa perusahaan yang mengalami peningkatan peluang pertumbuhan, maka tarif pajak efektif perusahaan semakin rendah yang menandakan bahwa perusahaan melakukan perencanaan pajak. Perusahaan yang memiliki tingkat penjualan yang besar akan memiliki kecukupan modal kerja operasional sehingga perusahaan berpotensi mendapatkan keuntungan yang meningkat. Meningkatnya keuntungan perusahaan sejalan dengan beban pajak 
Owner: Riset \& Jurnal Akuntansi

e-ISSN : 2548-9224 | p-ISSN : 2548-7507

Volume 6 Nomor 1, Januari 2022

DOI : https://doi.org/10.33395/owner.v6i1.567

yang perlu dibayar perusahaan. Hal ini mendorong perusahaan melakukan perencanaan pajak agar dapat mengoptimalkan keuntungan yang diperoleh perusahaan.

\section{Dampak Capital Intensity Ratio terhadap Perencanaan Pajak}

Hasil penelitian menunjukkan bahwa Capital Intensity Ratio berpengaruh negatif dan signifikan terhadap Perencanaan Pajak. Hasil penelitian ini mendukung hasil penelitian terdahulu yang menyatakan bahwa Capital Intensity Ratio mempengaruhi Perencanaan Pajak (Hazir, 2019) (Kim \& Im, 2017). Namun, hasil penelitian ini bertolak belakang dengan hasil penelitian terdahulu lainnya yang menyatakan bahwa Capital Intensity Ratio tidak mempengaruhi terhadap Perencanaan Pajak (Putra, Yuliusman, \& Wisra, 2020) (Irianto, Sudibyo, \& Wafirli, 2017) (Dias \& Reis, 2018) (Pattiasina, Tammubua, Numberi, Patiran, \& Temalagi, 2019) (Salawu \& Adedeji, 2017).

Dalam penelitian ini, Capital Intensity Ratio berpengaruh negatif signifikan terhadap perencanaan pajak. Pengaruh negatif ini menunjukkan bahwa semakin efisiensi perusahaan dalam menggunakan asetnya untuk menghasilkan penjualan, maka tarif pajak efektif perusahaan akan semakin rendah yang berarti bahwa perusahaan melakukan perencanaan pajak. Hal ini dikarenakan penggunaan asset tetap yang diikuti oleh beban depresiasi dapat mengurangi jumlah pajak yang dibayar perusahaan akibat berkurangnya laba diakhir periode. Hal ini bisa dimanfaatkan perusahaan untuk memanfaatkan pemilihan metode akuntansi terhadap depresiasi asset tetap. Sehingga, tingkat capital intensity ratio perusahaan yang semakin tinggi dapat menyebabkan tarif pajak efektif perusahaan menjadi rendah.

\section{KESIMPULAN}

Berikut adalah simpulan dari hasil penelitian ini dapat ditarik kesimpulan bahwa berdasarkan uji faktor, variabel komite audit merupakan exclude variable sehingga tidak dilanjutkan kedalam uji regresi berganda. Hasil pengujian secara simultan menjelaskan bahwa variabel kepemilikan institusional, proporsi dewan komisaris independen, dewan direksi, solvabilitas, profitabilitas, ukuran perusahaan, peluang pertumbuhan, dan capital intensity ratio merupakan determinan perencanaan pajak perusahaan pertambangan. Hasil pengujian secara parsial menunjukkan bahwa kepemilikan institusional, profitabilitas, peluang pertumbuhan dan Capital intensity ratio berpengaruh signifikan negatif terhadap Perencanaan Pajak. Hal ini berarti bahwa jika keempat faktor tersebut semakin tinggi, maka semakin menurunnya tarif pajak efektif perusahaan menandakan bahwa perusahaan melakukan perencanaan pajak. Hal ini berarti bahwa, bahwa perusahaan yang akan cenderung melakukan perencanaan pajak apabila perusahaan diawasi lebih oleh investor institusional, memiliki nilai profitabilitas, peluang pertumbuhan dan capital intensity ratio yang lebih tinggi. Bagi manajemen perusahaan, diharapkan dapat melihat faktorfaktor yang bisa digunakan menjadi penghemat pajak secara legal sehingga memperoleh tarif pajak yang efektif. Bagi pemerintah, diharapkan dapat lebih memperhatikan grey area yang bisa dimanfaatkan oleh perusahaan sebagai celah untuk mengurangi pembayaran pajak yang mengakibatkan berkurangnya pendapatan negara. Bagi peneliti selanjutnya, diharapkan dapat menambah variabel independen lain dan memperluas objek penelitian sehingga menghasilkan hasil penelitian yang baru untuk referensi bagi peneliti selanjutnya.

\section{REFERENSI}

Aburajab, L., Maali, B., Jaradat, M., \& Alsharairi, M. (2019). Board of Directors' Characteristics and Tax Aggressiveness : Evidence from Jordanian Listed Firms. Theoretical Economics Letters, 2732-2745.

Alfina, I. T., Nurlaela, S., \& Wijayanti, A. (2018). The Influence of Profitability, Leverage, Independent Commissioner, and Company Size to Tax Avoidance. The 2nd International Conference on Technology, Education, and Social Science 2018 (pp. 102-106). Solo: Universitas Slamet Riyadi. 
Arismajayanti, N. P., \& Jati, I. K. (2017). Influence of Audit Committee Competence, Audit Committee Independence, Independent Commisssioner and Leverage on Tax Aggressiveness. Journal of Auditing, Finance, and Forensic Accounting, 109-119.

Ayem, S., \& Setyadi, A. (2019). Pengaruh Profitabilitas, Ukuran Perusahaan, Komite Audit Dan Capital Intensity Terhadap Agresivitas Pajak. Jurnal Akuntansi Pajak Dewantara, 228241.

Chytis, E., Taslos, S., \& Filos, I. (2020). The Effect of Corporate Governance Mechanisms on Tax Planning During Financial Crisis: An Empirical Study of Companies Listed on The Athens Stock Exchange. International Journal of Disclosure and Governance, 30-38.

Dias, P. J., \& Reis, P. M. (2018). The Relationship Between The Effective Tax Rate and The Nominal Rate. Contaduría y Administración, 1-21.

Effendi, M. A. (2016). The Power of Good Corporate Governance : Teori dan Implementasi. Jakarta: Salemba Empat.

Egbunike, F. C., Gunardi, A., Ugochukwu, U., \& Hermawan, A. (2021). Internal Corporate Governance Mechanisms and Corporate Tax Avoidance in Nigeria: A Quantile Regression Approach. Jurnal Ilmiah Akuntansi dan Bisnis, 20-44.

Fauzan, Wardan, D. A., \& Nurharjanti, N. N. (2019). The Effect of Audit Committee, Leverage, Return on Assets, Company Size, and Sales Growth on Tax Avoidance. Riset Akuntansi dan Keuangan Indonesia, 171-185.

Ghozali, I. (2013). Aplikasi Analisis Multivariate Dengan Program IBM SPSS 21. Badan Penerbit Universitas Diponegoro.

Gunawan, Y., Christy, Y., Tin, S., \& Jonathan, L. (2021). The Influence of Independent Board of Commissioners, Audit Committee, and Audit Quality on Tax Avoidance. BALANCE: Economic, Business, Management, and Accounting Journal, 42-49.

Hazir, C. A. (2019). Determinants of Effective Tax Rates in Turkey. Journal of Research in Business, 35-45.

Hery. (2017). Kajian Riset Akuntansi. Jakarta: PT Grasindo.

Idzniah, U. N., \& Bernawati, Y. (2020). Board of Directors, Audit Committee, Executive Compensation, and Tax Avoidance of Banking Companies in Indonesia. Journal of Accounting and Strategic Finance, 199-213.

Imuetinyan, I. B., Solomon, E. A., \& Jonathan, A. (2019). Effect of Board Characteristics, Firms Performance and Effective Tax Planning in Nigeria Food Manufacturing Sector. FUO Quarterly Journal of Contemporary Research, 1-12.

Indriani, M. D., \& Juniarti. (2020). Influence of Company Size, Company Age, Sales Growth, and Profitability on Tax Avoidance. Indonesian College of Economics, 1-18.

Irianto, B. S., Sudibyo, Y. A., \& Wafirli, A. (2017). The Influence of Profitability, Leverage, Firm Size and Capital Intensity Towards Tax Avoidance. International Journal of Accounting and Taxation, 33-41.

Jamei, R. (2017). Tax Avoidance and Corporate Governance Mechanisms: Evidence from Tehran Stock Exchange. International Journal of Economics and Financial Issues, 638-644.

Januari, D. M., \& Suardikha, I. S. (2019). Pengaruh Corporate Social Responsibility, Sales Growth, dan Profitabilitas Terhadap Tax Avoidance. E-Jurnal Akuntansi Universitas Udayana, 1653-1677.

Jumingan. (2014). Analisis Laporan Keuangan. Jakarta : PT Bumi Aksara.

Kasmir. (2015). Analisis Laporan Keuangan. Jakarta: PT RajaGrafindo Persada .

Katadata. (2020, February 12). Retrieved from https://katadata.co.id: https://katadata.co.id/opini/2019/02/11/gelombang-penghindaran-pajak-dalam-pusaranbatu-bara

Khan, M., Srinivasan, S., \& Tan, L. (2017). Institutional Ownership and Corporate Tax Avoidance: New Evidence. The Accounting Review, 101-122.

Kim, J. H., \& Im, C. C. (2017). The Study On The Effect And Determinants Of Small - And Medium-Sized Entities Conducting Tax Avoidance. The Journal of Applied Business Research, 375-390. 
Kuswiratmo, B. A. (2016). Keuntungan \& Risiko Menjadi Direktur, Komisaris, dan Pemegang Saham. Jakarta: Visimedia.

Mappadang, A. (2021). Corporate Governance and Corporate Tax Avoidance: an Interactive Effects. Jurnal Keuangan dan Perbankan, 81-92.

Nuryatun, \& Mulyani, S. D. (2020). The Role of Independent Commissioners in Moderating The Effect of Transfer Pricing, Capital Intensity and Profitability Towards Tax Aggressivity. Indonesian Management and Accounting Research, 181-204.

Otoritas Jasa Keuangan. (2014). Peraturan Otoritas Jasa Keuangan Nomor 33/POJK.04/2014 Tentang Direksi dan Dewan Komisaris Emiten atau Perusahaan Publik. Jakarta: Otoritas Jasa Keuangan.

Pangaribuan, H., HB, J. F., Agoes, S., Sihombing, J., \& Sunarsi, D. (2021). The Financial Perspective Study on Tax Avoidance. Budapest International Research and Critics Institute, 4998-5009.

Pattiasina, V., Tammubua, M. H., Numberi, A., Patiran, A., \& Temalagi, S. (2019). Capital Intensity and Tax Avoidance: A Case in Indonesia. International Journal of Social Sciences and Humanities, 58-71.

Pohan, C. A. (2013). Manajemen Perpajakan: Strategi Perencanaan Pajak dan Bisnis. Jakarta: Gramedia Pustaka Utama.

Prasetyo, A., Masitoh, E., \& Wijayanti, A. (2018). The Influence of Good Corporate Governance, Capital Intensity Ratio, and Profitability to Effective Tax Rate. The 2nd International Conference on Technology, Education, and Social Science 2018 (The 2nd ICTESS 2018), (pp. 73-82).

Putra, W. E., Yuliusman, \& Wisra, R. F. (2020). The Relations Among Firm Characteristic, Capital Intensity, Institutional Ownership, and Tax Avoidance: Some Evidence From Indonesia. Humanities \& Social Sciences Reviews, 315-322.

Putri, A. A., Azmi, Z., \& Arsa, J. (2021). Do Sales Growth, Leverage and Capital Intensity affect Tax Avoidance? Jurnal Akuntansi \& Ekonomika, 1-11.

Putri, G. P., Setiawan, V., Faishol, A., Roza, F., \& Yudha, F. P. (2018). Does Corporate Governance Affect Tax Planning? A Case Study of a Manufacturing Company. Research Journal of Finance and Accounting, 95-101.

Rosidy, D., \& Nugroho, R. (2019). Pengaruh Komisaris Independen dan Kompensasi Eksekutif Terhadap Agresivitas Pajak. Jurnal Info Artha, 55-65.

Salaudeen, Y. M., \& Ejeh, B. U. (2018). Equity Ownership Structure and Corporate Tax Aggressiveness: The Nigerian Context. Research Journal of Business and Management, 90-99.

Salawu, R. O., \& Adedeji, Z. A. (2017). Corporate Governance and Tax Planning Among NonFinancial Quoted Companies in Nigeria. International Association of African Researchers and Reviewers, 42-59.

Santini, A. L., \& Indrayani, E. (2020). The Effect of Profitability, Liquidity, Leverage, Capital Intensity and Firm Size on Tax Aggressiveness With Market Performance as an Intervening Variable. Jurnal Ilmiah Ekonomi Bisnis, 290-303.

Sonia, \& Suparmun, H. (2018). Factors Influencing Tax Avoidance. Advances in Economics, Business and Management Research, 238-243.

Sugiyono. (2016). Metode Penelitian Administrasi. Bandung: Alfabeta.

Tunggal, A. W. (2016). Memahami Pekerjaan Akuntan Publik di Pasar Modal. Jakarta: Harvindo.

Waluyo. (2017). The Effect of Good Corporate Governance on Tax Avoidance: Empirical Study of The Indonesian Stock Banking Company. The Accounting Journal of BINANIAGA.

Zaini, Z. (2016). Execution Matters. Jakarta: PT Gramedia Pustaka Utama. 